\title{
Information in Financial Statement Misstatements at the Engagement Partner Level: A Case for Engagement Partner Name Disclosure?
}

\author{
Wuchun Chi \\ National Chengchi University \\ wchi@nccu.edu.tw \\ Ling Lei Lisic \\ George Mason University \\ llisic@gmu.edu \\ Linda A. Myers \\ University of Arkansas \\ lmyers@walton.uark.edu \\ Mikhail Pevzner \\ University of Baltimore \\ mpevzner@ubalt.edu
}

January 2015

We thank Dick Larsen, Matt Medlin, James Myers, participants at the 2013 AAA Auditing Section Midyear
Meeting, and workshop attendees at George Mason University and National University of Singapore for their
helpful comments and insights. We also thank Samwa Hsieh for excellent research assistance. Wuchun Chi
gratefully acknowledges financial support from the National Science Council (101-2410-H-004-073), Linda Myers
gratefully acknowledges financial support from the Garrison/Wilson Chair at the University of Arkansas, and
Mikhail Pevzner gratefully acknowledges support from the EY Chair in Accounting at the University of Baltimore. 


\title{
Information in Financial Statement Misstatements at the Partner Level: A Case for Engagement Partner Name Disclosure?
}

\begin{abstract}
Using data from Taiwan where engagement partner names are disclosed and misstatements of clients' annual financial statements to proxy for audit quality, we examine whether audit quality at the engagement partner level persists, and whether an engagement partner's reputation for prior audit quality is informative about current audit quality. We find that at the engagement partner level, year $t-1$ misstatements made by other audit clients predict year $t$ misstatements for clients without a history of misstatements in the preceding three years, but this effect is mitigated by engagement partner experience. In addition, we find a positive association between the incidence of restatements made by an engagement partner's clients in the previous two or three years and the likelihood that a different client misstates in the current year, suggesting that partner-level restatements provide information about future audit quality. Finally, we find that an engagement partner's reputation for past client misstatements (as disclosed in restatements) is associated with a higher likelihood of that partner losing existing clients and a lower likelihood of that partner attracting new audit clients. Collectively, our results suggest that engagement partner identification can reveal information that is informative about audit quality and affects stakeholder perceptions of audit quality, providing some support for the Public Company Accounting Oversight Board's proposal to disclose the names of engagement partners in the U.S.
\end{abstract}

Keywords: audit quality, engagement partners, misstatements, restatements 


\section{INTRODUCTION}

After soliciting public comment on a 2009 concept release that would require engagement partners to sign their audit reports, in October 2011, the Public Company Accounting Oversight Board (PCAOB) formally proposed that names of engagement partners be disclosed. The original concept release argued that requiring engagement partner signatures could improve audit quality in two ways. First, it might increase the engagement partner's sense of accountability to financial statement users, which could lead him or her to exercise greater care in performing the audit. Second, it would increase transparency about who is responsible for performing the audit, which could provide useful information to investors and, in turn, provide an additional incentive to firms to improve the quality of all of their engagement partners

(PCAOB 2009, p. 5). The 2009 concept release and 2011 proposal generated strong responses

from investors, academics, and practitioners. A comment letter written by the Texas Society of

Certified Public Accountants (TSCPA) states:

We believe this [exposure draft] has many flaws in both the basis for its issuance and the guidance it proposes... The justification for this document appears to come from the views of the Council of Institutional Investors and inconclusive research provided by the academic community. The focus of the document seems to be on rectifying the inadequacies of those in charge of audit engagements by identifying them and publicizing the perception of their inappropriate performance. We believe this is a very poor basis for the development of an auditing standard!

Interestingly, the TSCPA's comment letter claims that the PCAOB's exposure draft is based on "inconclusive research provided by the academic community" (TSCPA 2011, p. 1).

In 2013, the PCAOB formally reproposed the standard, again requiring engagement partner name disclosure. Commenting on the 2013 reproposed standard, PCAOB Chairman James Doty remarked that the requirement "holds the promise of improving audit quality by sharpening the mind and reminding auditors of their responsibility to the public." "The PCAOB's position seems to imply that, in addition to increasing an engagement partner's sense of

\footnotetext{
${ }^{1}$ See http://pcaobus.org/News/Speech/Pages/12092013_Doty_AICPA.aspx.
} 
accountability, engagement partner reputation should be informative about audit quality. ${ }^{2}$

Moreover, PCAOB board member Louis Ferguson argued that the 2013 reproposed standard

would result in greater transparency about the engagement partner's reputation for audit quality: ${ }^{3}$

I do think over time ... that information will be gathered about these auditor partners, probably by third-party information providers, including things like the industry experience of that auditor, the public companies with which the auditor has been associated, whether the auditor has been involved in public disciplinary proceedings or litigation or been involved in publicly-disclosed financial restatements, as well as information about the professional activities of the auditor. I believe that this would be useful information to investors.

Despite its expected benefits, the proposal has received strong opposition from some

audit practitioners, who argue that the current practice of signing the audit firm name already

makes the firm as well as individual audit partners responsible for the quality of the audit report. ${ }^{4}$

In addition, the sentiments in the TSCPA's comment letter were echoed by PCAOB board

member Jeannette Franzel, who, when the PCAOB reproposed this standard in late 2013, stated: ${ }^{5}$

I'm starting to think that naming the audit engagement partner in the auditor's report is a solution in search of a problem. First, as I said, the objectives of this project are difficult to follow over its various iterations. Second, the current release does not articulate how the proposed solution addresses any particular problem; nor does it present an analysis of benefits that is supported by data. Finally, many questions remain unanswered about the potential costs and exposure of auditors to additional liability.

\footnotetext{
2 This is consistent with arguments related to the recent conviction of senior KPMG partner Scott London for insider trading activities. For example, in light of this revelation, defense attorney Patrick Craine argued, "If you look at a case like this, KPMG initially failed to disclose the name of the audit partners involved. Even once the name of the audit partner was disclosed, you had no idea what other audits he may have been leading. And as an investor, it would have been very interesting to know what other audits he was leading because they were likely to have implications as well..." Also see "PCAOB Could Toughen Auditor Rules after KPMG Insider Trading Case" at accountingtoday.com (April 12, 2013), available at: http://www.accountingtoday.com/debits_credits/PCAOBAuditor-Rules-KPMG-Insider-Trading-Case-66350-1.html.

${ }^{3}$ See http://pcaobus.org/News/Speech/Pages/12042013_Ferguson_oral.aspx.

${ }^{4}$ See, for example, http://pcaobus.org/Rules/Rulemaking/Docket029/014b_TSCPAs.pdf. Moreover, the minutes of the PCAOB's November 9, 2011 Standing Advisory Group meeting state, “...it would be misleading because the audit is... a collective enterprise and requires resources of many, many different people in the firm" (see http://pcaobus.org/Rules/Rulemaking/Docket029/11092011_SAG_Transcript_Excerpt_and_Slides.pdf). ${ }^{5}$ See http://pcaobus.org/News/Speech/Pages/12042013_Franzel_Transparency.aspx.
} 
PCAOB board member Jay Hanson also expressed concerns that the reproposed engagement partner disclosure has not been proven beneficial and is potentially risky. ${ }^{6}$ Finally, the Illinois CPA Society stated, "We believe that the disclosure of the engagement partner's name and information about other participants in the audit will not provide truly useful information to investors and other financial statement users. While the information may be 'used' for numerous purposes ... the how, why or to what extent that information may really be 'useful' is not evident."

Responding to this debate, in December 2013, the PCAOB formally requested comments on their reproposed standard. ${ }^{8}$ The request for comments asks,

Over time, would the reproposed requirement to disclose the engagement partner's name allow databases and other compilations to be developed in which investors and other financial statement users could track certain aspects of an individual engagement partner's history, including, for example, his or her industry expertise, restatement history, and involvement in disciplinary proceedings or other litigation? a. Would such databases or compilations be useful to investors and other financial statement users? If so, how?

b. Would they provide investors and audit committees with relevant benchmarks against which the engagement partner could be compared? If so, how?

Once again, objections were voiced from a variety of sources. ${ }^{9}$

Because evidence on the purported benefits of engagement partner name disclosure is scant, our first goal is to provide evidence on whether such disclosure can be informative about

\footnotetext{
${ }^{6}$ See http://pcaobus.org/News/Speech/Pages/12042013_Hanson_Transparency.aspx.

${ }^{7}$ See http://pcaobus.org/Rules/Rulemaking/Docket029/019c_ILCPAS.pdf.

${ }^{8}$ See http://pcaobus.org/Rules/Rulemaking/Docket029/PCAOB\%20Release\%20No\%20\%202013-009\%20-

\%20Transparency.pdf.

${ }^{9}$ According to "PCAOB Proposal to Name Engagement Partner May Generate Debate" in Journal of Accountancy (December 2, 2013), available at: http://www.journalofaccountancy.com/News/20139121.htm: BDO stated, "[w]e believe that there is already a sufficient level of accountability in the existing environment, obviating the need for engagement partner identification"; the Audit and Assurance Services Committee of the Illinois CPA Society stated, "[ $[$ ] he name of the engagement partner would provide no more protection to investors than the names of the chief of drilling operators of oil companies could protect the Gulf of Mexico from oil spills"; EY stated, "[w]e do not believe that a partner's name would add anything useful to the total mix of information relied upon by investors and will likely cause some persons to make incorrect inferences about audit partners and audits"; and the Accounting Principles and Auditing Standards Committee of the California Society of CPAs stated, "[t]he name of the engagement partner is not meaningful information to investors."
} 
audit quality. Another of our goals is to examine whether certain mechanisms such as engagement partner experience can mitigate the persistence of misstatements at the engagement partner level. Our final goal is to investigate whether companies use the information available from engagement partner name disclosures when making partner engagement decisions.

Using data from Taiwan, where engagement partners are required to sign the audit reports (so engagement partner names disclosed), ${ }^{10}$ we examine whether annual financial statement misstatements and financial statement restatements (i.e., publicly disclosed corrections of prior period misstatements) can provide information about future annual financial statement misstatements of other clients with the same engagement partner in charge. In our tests, we exclude companies that have misstated in the past three years so that our results are not a function of client-specific financial reporting quality. ${ }^{11}$ First, we examine whether companies with an engagement partner whose other clients misstated their annual financial statements in the past year are more likely to misstate their annual financial statements in the current year (relative to companies with an engagement partner whose other clients did not misstate their annual financial statements in the past year). In addition, we examine whether this "persistence of misstatements" is affected by the engagement partner's general audit experience, industryspecific experience, or client-specific tenure. We also test whether revealed misstatements (in the form of restatements) in prior years provides information about the likelihood that the engagement partner's other clients misstate in the current year. Finally, because the loss of audit clients or the inability to attract new audit clients following restatement announcements suggests that the audit market penalizes engagement partners for poor audit quality, we examine whether

\footnotetext{
10 "Although identifying the engagement partner by name is not identical to requiring the partner to sign the report, such public identification may serve to increase partner accountability and transparency" (Carcello and Li 2013, p. 1512).

${ }^{11}$ In untabulated analyses, however, we find that our results are stronger when we retain these companies.
} 
an engagement partner is more likely to lose audit clients and/or less likely to attract new audit clients after at least one of his clients restates.

Francis and Michas (2013) find that audit failures tend to cluster in audit offices but because engagement partner-level data are not available in the U.S., they cannot explore whether audit failures cluster by engagement partner. We suggest that the office level clustering documented in Francis and Michas (2013) should be a product of audit quality provided by specific individual engagement partners in those offices. Consistent with this, we find that the likelihood of a company misstating its financial statements in the current year is significantly higher if at least one of its engagement partner's other clients misstated their annual financial statements in the prior year.

We posit that engagement partner experience could affect audit quality because experience may affect engagement partners' ability to detect their clients' aggressive accounting choices (or their willingness to allow clients to make these choices). Research using data from Australia and Taiwan finds that engagement partner tenure is associated with proxies for audit quality (Carey and Simnett 2006, Chen et al. 2008). ${ }^{12}$ We find that an engagement partner's general audit experience reduces the persistence of misstatements, suggesting that general audit experience is important for ensuring higher audit quality. ${ }^{13}$

We also suggest that individual engagement partners build reputations for audit quality, ${ }^{14}$

\footnotetext{
${ }^{12}$ For example, Carey and Simnett (2006) find that in Australia, longer engagement partner tenure is associated with greater earnings management (i.e., higher levels of discretionary accruals and a higher propensity to meet or just beat earnings expectations) as well as a lower likelihood of issuing going concern opinions. Alternatively, Chen et al. (2008) find evidence consistent with engagement partner tenure reducing earnings management in Taiwan. ${ }^{13}$ Interestingly, our discussions with a former senior partner of a Big 4 audit firm reveal that larger audit firms commonly assign more senior engagement partners as 'senior advisory partners' on audit engagements in order to ensure that less experienced engagement partners do not acquiesce to client demands. However, whether advisory engagement partner experience can effectively restrain aggressive accounting practices is unclear. For example, the senior partner assigned to David Duncan failed prevent the Arthur Andersen-Enron debacle (Squires et al. 2003). ${ }^{14}$ Consistent with this, Koch (2011) finds that engagement partner experience affects audit pricing in Germany.
} 
and that the public disclosure of misstatements (in the form of restatements) can be informative about future audit quality and about perceptions of audit quality. Specifically, we find that restatements issued by an engagement partner's clients in the past two or three years are associated a higher likelihood of that engagement partner's other clients misstating in the current year. Finally, we find that an engagement partner with a history of past restatements is more likely to lose existing clients and less likely to attract new audit clients.

Overall, our study provides evidence that the disclosure of individual engagement partner names is informative about audit quality for companies in Taiwan. As such, our findings provide indirect support for the PCAOB's proposal to disclose engagement partner names.

Our paper proceeds as follows. Section 2 reviews the literature and develops our hypotheses. Section 3 describes our sample selection methodology and research design. Section 4 describes the sample and presents empirical results. Section 5 concludes.

\section{LITERATURE REVIEW AND DEVELOPMENT OF HYPOTHESES}

Until recently, researchers have focused on audit firm-level auditor characteristics as determinants of financial reporting quality. The literature concludes that financial reporting quality is higher when the audit firm is large (i.e., is one of the Big $\mathrm{N}$ audit firms), has industry expertise, and has longer tenure with the client (Francis 2011, Knechel et al. 2013). However, Francis (2011) suggests supplementing findings at the audit firm-level with research on the impact of individual auditors. We answer the call for engagement partner-level research in Francis (2011) and argue that characteristics of the individual auditors conducting the audit matter for audit quality.

An engagement partner's ability to exercise professional skepticism and withstand pressure from clients is critical, especially when the client is important to the audit firm and/or to 
the partner's client portfolio. Experimental evidence suggests that an audit partner's inherent traits affect his level of skepticism (Hurtt et al. 2008). Moreover, engagement partners lead other members of the audit team and tend to steer audit team judgments towards their own (Peytcheva and Gillett 2011). For instance, when audit managers perceive stronger partner pressure to retain clients, they are more likely to acquiesce to the client's aggressive accounting choices (Cohen and Trompeter 1998). Similarly, an engagement partner's focus on audit efficiency can lead audit managers to place inappropriate reliance on the work of internal auditors and to exercise lower levels of professional skepticism (Brown et al. 1999, Gramling 1999, Knechel et al. 2013). Exacerbating this problem, Messier et al. (2008) find that engagement partners tend to be overconfident about their subordinates' abilities to detect accounting malfeasance (although concurring partner reviews can reduce bias (Woods 2011, Knechel et al. 2013).

Because individual engagement partners are key to audit quality, an engagement partner's reputation for conducting high quality audits or, importantly, low quality audits should be informative to financial statement users. This is one of the basic arguments in the PCAOB's proposal to require companies to disclose engagement partner names. Thus, the PCAOB seeks public comments on whether knowledge of the partner's identity would allow financial statement users to access information about the partner's experience which could serve as a signal about the quality of the engagement partner's performance.

Consistent with the notion that knowledge engagement partner names can be useful, some prior research suggests that individual engagement partner characteristics affect audit quality. For example, recent work by Carcello and Li (2013) finds that when partners are required to sign their audit reports in the U.K., abnormal accruals and the likelihood that their clients beat earnings benchmarks falls. In addition, using data from Sweden, Knechel et al. 
(2015) find that both aggressive and conservative auditor reporting, measured by the frequency of Type I and Type II going concern error rates, persist over time and extend across an engagement partner's clients. ${ }^{15}$ Our study complements Knechel et al. (2015) because we include companies that are not financially distressed and we examine the persistence of misstatements, which are more prevalent than going concern opinions.

Prior research also suggests that engagement partner characteristics are important for audit quality. For example, Chin and Chi (2009) find that engagement partner expertise (i.e., industry-specific market share) is associated with a lower likelihood of future restatements. In addition, Francis (2011, p. 138) argues that "partners will face more threats to their objectivity and independence if their compensation is locally tied to their personal portfolios or to officelevel clienteles." Consistent with this reasoning, experimental evidence suggests that when engagement partner compensation is tied to client retention, downward audit adjustments are less likely (Trompeter 1994). Thus, poorly structured engagement partner compensation arrangements could lead to an increase in the likelihood of client misstatements but these compensation arrangements cannot be publicly observed.

An emerging literature suggests that top executives' individual preferences and riskaversion impact firms' financial and accounting policies (e.g., Bamber et al. 2010, Ge et al. 2011, McGuire et al. 2012). We suggest that, similarly, individual engagement partner characteristics should matter for audit quality. Because individual engagement partner-level data are not available in the U.S., direct support for the notion that the likelihood of audit failures varies across individual partners cannot be found in the U.S. audit market. U.S.-based audit research

\footnotetext{
${ }^{15}$ Type I errors result when going concern opinions are issued to non-failing clients and Type II errors result when failing clients do not receive going concern opinions. The observed frequencies of Type I and Type II errors are indirect measures of audit quality because what causes auditors to issue or not issue going concern opinions in different situations it is not entirely clear (Knechel et al. 2013).
} 
therefore tends to focus on whether audit firm characteristics are determinants of financial reporting quality (Francis 2011, Knechel et al. 2013). More recently, however, archival research has begun to investigate the impact of office-level audit characteristics. The logic behind these studies is that because individual offices are autonomous, have different human capital profiles and different client profiles, and generally represent client portfolios with undiversified audit risk, audit quality is likely to vary by office. Consistent with this reasoning, Francis and Yu (2009) find that audit office size (measured using total audit fees) is negatively associated with discretionary accruals. In addition, Francis and Michas (2013) find that the presence of accounting restatements in a particular office is associated with higher abnormal accruals among non-restating clients in that office, and with a higher likelihood of future restatements in that office. We suggest that these office-level results may be related, at least in part, to the effects of individual partners in these offices.

We note, however, that there are reasons to believe that we might not observe difference in audit quality across engagement partners. For example, the TSCPA's comment letter argues that audit firms' quality control policies, professional ethics, rules, and peer review programs can prevent systematic malfeasance by certain engagement partners. ${ }^{16}$ Moreover, Hilary and Lenox (2005) suggest that audit firms' peer review programs can improve audit quality because negative peer review opinions result in client losses. Thus, at least some negative individual engagement partner effects on audit quality could be mitigated by firm- and profession-level

\footnotetext{
${ }^{16}$ See "RE: Improving the Transparency of Audits: Proposed Amendments to PCAOB Auditing Standards and Form 2," available at: http://www.accountingtoday.com/news/TSCPAletterPCAOBImprovingTransparencyinAudits.php. Note, however, that academic research finds that quality control policies within firms, while generally beneficial, are not always effective. Some factors identified in prior literature as negatively affecting quality control reviews are known reviewer preferences, partner over-confidence, assumed preparer reputation, and congruency of the opinions of reviewers and preparers. These negative factors can be mitigated, however, when the level of review is higher (Knechel et al. 2013).
} 
institutional safeguards. Given that there is some question about whether audit quality is observable at the audit partner level, we test our first alternative hypothesis:

H1: The likelihood that a client misstates its annual financial statements will be higher if at least one of its engagement partner's other clients misstated its annual financial statements in the prior year.

Prior research demonstrates that longer engagement partner tenure is associated with higher accounting quality (Manry et al. 2008) and also finds that more experienced auditors are better at detecting financial statement errors, have more accurate knowledge of error occurrence rates, and are better able to categorize errors (Libby and Frederick 1990). Thus, misstatements associated with more experienced auditors (i.e., engagement partners with more general audit experience, experience in the client's industry, or experience with a given client (i.e., tenure) could be more transitory in nature. We investigate this possibility in our empirical tests.

Past misstatements become public when companies restate their financial statements. Thus, we investigate whether past restatements issued by an engagement partner's clients provide information about the likelihood that other clients will misstate in the current year. Because misstatements take some time to be revealed as restatements and because market participants can consider an engagement partner's history of misstatements, in our empirical tests, we focus on the incidence of restatements over the past two and three years.

Finally, prior literature suggests that clients suffer adverse consequences when they restate. For example, the market penalizes restating companies with negative stock price reactions (Palmrose et al. 2004), an increased cost of capital (Hribar and Jenkins 2004), and higher executive turnover (Desai et al. 2006). Moreover, companies take actions to 'repair' their tarnished reputations after restatements (Chakravarthy et al. 2014). Prior research also finds that audit firms are more likely to lose clients and/or are less likely to gain new clients following 
problems with audit quality, ${ }^{17}$ and Whited (2013) finds that reputation effects are located at the audit office level in that audit offices associated with past restatements experience market share losses. We extend this thinking to the engagement partner level. Specifically, because restatements are costly to clients, both in terms of audit fees and market perceptions, ${ }^{18}$ audit clients should want to avoid engaging partners whose audits are associated with subsequent financial statement restatements. If certain partners are known to provide lower quality audits, we expect their personal reputations to suffer, reducing their ability to attract new business and to retain their current clients. Furthermore, because audit firms are likely to care about the quality of audit work provided by their partners, they may reassign the clients of partners associated with audit failures to other partners or may avoid assigning newly engaged clients to partners associated with lower quality audits. In either case, audit failures (in the form of restatements), should be associated with future client losses. ${ }^{19}$ Thus, our second alternative hypothesis is as follows:

H2: Restatements are associated with a higher likelihood of client losses and a lower likelihood of new client acquisitions at the engagement-partner level.

\section{SAMPLE SELECTION, METHODOLOGY, AND RESEARCH DESIGN}

We use data from Taiwan to test our hypotheses because in Taiwan, audit reports include the names of the two engagement partners along with the name of the audit firm. Following Chin

\footnotetext{
${ }^{17}$ See, for example, Firth (1990), Wilson and Grimlund (1990), Hillary and Lennox (2005), Blouin et al. (2007), Weber et al. (2008), Daugherty et al. (2011), Skinner and Srinivasan (2012), Abbott et al. (2013), Boone et al. (2014), and Hennes et al. (2014).

${ }^{18}$ For example, Feldmann et al. (2009) document an average decrease in audit fees of 17 percent following a restatement and Palmrose et al. (2004) document an average stock price reaction of -9 percent to restatements announced in the U.S. during the pre-Sarbanes Oxley period.

${ }^{19}$ This is also consistent with results in Lambert et al. (2012), which show that in an experimental setting, prospective investors are less willing to invest in a company audited by an engagement partner with a previously restating client.
} 
and Chi (2009), we focus on the lead signing partner in all of our analyses. ${ }^{20}$ Another unique feature of the Taiwanese audit market is that data are available for both publicly listed and privately owned companies. ${ }^{21}$ We use the database provided by the Taiwan Economic Journal (TEJ) to collect all publicly disclosed financial statement data. Thus, we can include the engagement partner's publicly listed clients and unlisted clients in our analyses.

$\mathrm{H} 1$ predicts that a client is more likely to misstate if its engagement partner was associated with at least one misstatement made by other clients in the prior year. This hypothesis conjectures that audit quality is 'sticky' at the engagement partner level. To test H1, we follow prior research (Hribar and Jenkins 2004, Palmrose et al. 2004, Desai et al. 2006, Cao et al. 2012) and use the likelihood of misstatements to proxy for audit quality. We estimate the following logit regression:

$$
\begin{aligned}
& \text { MISSTATE }_{t}=a_{0}+a_{1} \text { MISSTATE_PARTNER } R_{t-1} \\
& +a_{2} L O N G \_P A R T N E R \_G E N \_E X P E R I E N C E_{t} \\
& +a_{3} L O N G \_P A R T N E R \_I N D \_E X P E R I E N C E_{t}+a_{4} L O N G \_P A R T N E R \_T E N U R E_{t} \\
& +a_{5} P A R T N E R \_I N D \_E X P E R T_{t}+a_{6} M I S S T A T E_{-} \text {FIRM } M_{t-1}+a_{7} F I R M_{-} \text {TENURE } \\
& +a_{8} \text { LASSET }_{t}+a_{9} \triangle \text { ASSET }_{t}+a_{10} \text { AR_IN }_{t-1}+a_{11} \text { FOREIGN }_{t-1}+a_{12} \text { FINANCING }_{t-1}
\end{aligned}
$$

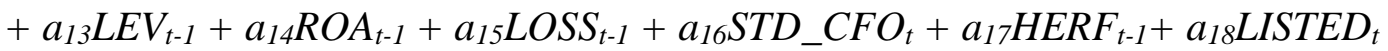

$$
\begin{aligned}
& +a_{19} O W N E R S H I P_{t-1}+a_{20} L B O A R D \_S I Z E_{t-1}+e_{t}
\end{aligned}
$$

Where:

MISSTATE $=$ an indicator variable set equal to one if the current year's annual financial statements are misstated, and zero otherwise;

\footnotetext{
${ }^{20}$ Chin and Chi (2009, p. 731) state that the lead signing engagement partner "typically directs the total effort, interprets the audit evidence, and ultimately determines the appropriate audit report (Francis et al. 1999; Reynolds and Francis 2000). Finally, the lead partner generally exhibits more hands-on experience during the audit engagement than the concurring partner (Reynolds and Francis 2000)." Consistent with this argument, Chin and Chi (2009) find that the industry experience of the lead engagement partner has a stronger effect on audit quality than that of the concurring partner. Thus, we limit our analyses to the lead signing partner.

${ }^{21}$ The Taiwan Securities and Exchange Act mandates that all companies issuing securities, including those listed on the Taiwan Stock Exchange Corporation and GreTai Securities Market as well as unlisted companies, publicly disclose audited financial statements. Before 2001, the mandatory reporting requirement applied to both publicly listed and privately held companies with contributed capital exceeding a certain threshold (Taiwan dollars (TWD) 200 million after 1981 and TWD 500 million after 2000). The reporting requirement for privately held companies was rescinded in 2001 so public disclosure of audited financial statements was at management's discretion. Thus, not all unlisted companies are included in the TSE database.
} 
MISSTATE_PARTNER

LONG_PARTNER_ GEN_EXPERIENCE

LONG_PARTNER IND_EXPERIENCE
$=$ an indicator variable set equal to one if the client's engagement partner was associated with at least one misstatement (made by another client) in the past year, and zero otherwise;

$=$ an indicator variable set equal to one if the engagement partner's general audit experience to date exceeds the sample mean, and zero otherwise, where general audit experience is measured as number of years since the partner was first identified in the TEJ database;

$=$ an indicator variable set equal to one if the engagement partner's industry experience to date exceeds the sample mean, and zero otherwise, where industry experience is measured as number of years that the partner has audited clients in the given 2-digit TEJ code industry;

LONG_PARTNER_TENURE = an indicator variable set equal to one if the engagement partner's client tenure to date exceeds the sample mean, and zero otherwise, where client tenure is defined as the length of the engagement partner-client relationship;

PARTNER_IND_EXPERT = an indicator variable set equal to one if the engagement partner is an industry expert, and zero otherwise, where an industry expert is defined as the engagement partner with the largest number of clients in the 2-digit TEJ code industry (following Chin and Chi (2009));

MISSTATE_FIRM

FIRM_TENURE

LASSET

$\triangle A S S E T$

AR_IN

FOREIGN

FINANCING
$=$ an indicator variable set equal to one if the audit firm was associated with at least one misstatement (made by another client) in the prior year, and zero otherwise;

$=$ the length of the audit firm-client relationship to date;

$=$ the natural $\log$ of total assets, to proxy for company size;

$=$ the percentage change in total assets during the year, to proxy for growth;

$=$ the sum of accounts receivable and inventory deflated by total assets;

$=$ the proportion of company sales generated in foreign countries, to proxy for a complexity;

$=$ an indicator variable set equal to one if the number of shares outstanding increases by at least 10 percent or if the value of long- 
$L E V$

$R O A$

LOSS

STD_CFO

HERF

LISTED

OWNERSHIP

LBOARD_SIZE

$t$

term debt increases by at least 20 percent during the year, and zero otherwise (following Cao et al. (2012));

$=$ leverage, measured as the ratio of total debt to total assets;

$=$ return on assets (i.e., net income divided by average total assets), to proxy for company profitability;

$=$ an indicator variable set equal to one if the company reports negative net income in the year, and zero otherwise;

$=$ the standard deviation of operating cash flows over the prior four years;

= industry concentration, measured using the Herfindahl index;

$=$ an indicator variable set equal to one if the company is listed on a stock exchange, and zero otherwise;

$=$ the percentage of common stock owned by insiders, where insiders are defined as managers, directors, and members of the supervisory board;

$=$ the natural $\log$ of board size; and

$=$ a year indicator.

In all of our regression models, we winsorize all continuous variables at their $1^{\text {st }}$ and $99^{\text {th }}$

percentiles to mitigate the influence of potential outliers. We also cluster-adjust all test statistics

at the audit client and year levels (Gow et al. 2010) and include industry fixed effects. We follow

Cao et al. (2012) to the extent possible when selecting control variables that affect

misstatements. $^{22}$

\footnotetext{
${ }^{22}$ We do not include company reputation, mergers and acquisitions, and the number of segments because this information is not available in Taiwan. In addition, audit fees and non-audit fees are required disclosures only when the ratio of non-audit to audit fees at least 0.25 or the amount of non-audit fees is at least 500,000 TWD, the client switches audit firms and the subsequent audit fees are less than the previous audit fees, or when audit fees are at least 15 percent lower than in the prior year. We do not include market-to-book ratio and stock return volatility because our sample includes non-listed companies. We do not include board independence because these data are not machine-readable for our sample. Finally, we consider financing activity but use a different measure since the measure in Cao et al. (2012) requires data about mergers and acquisitions (which are unavailable).
} 
H1 predicts a positive coefficient on MISSTATE_PARTNER $R_{t-1}$. That is, we expect that a client will be more likely to misstate its annual financial statements if at least one of its engagement partner's other clients misstated their annual financial statements in the prior year.

In addition, if audit quality is persistent at the audit-firm level, we would expect a positive coefficient on MISSTATE_FIRM $M_{t-1}$.

We further examine whether the ability of prior misstatements to predict future misstatements varies with engagement partner experience as follows:

$$
\begin{aligned}
& \text { MISSTATE }_{t}=\lambda_{0}+\lambda_{l} \text { MISSTATE_PARTNER }_{t-1} \\
& +\lambda_{2} L O N G \_P A R T N E R \_G E N \_E X P E R I E N C E_{t} \\
& +\lambda_{3} \text { MISSTATE_PARTNER }{ }_{t-1} * L O N G \_P A R T N E R \_G E N \_E X P E R I E N C E_{t} \\
& +\lambda_{4} L O N G \_P A R T N E R \_I N D \_E X P E R I E N C E_{t} \\
& +\lambda_{5} \text { MISSTATE_PARTNER } t-1 * L O N G_{-} \text {PARTNER_IND_EXPERIENCE }{ }_{t} \\
& +\lambda_{6} L O N G \_P A R T N E R \_T E N U R E_{t} \\
& +\lambda \text { MISSTATE_PARTNER } R_{t-1} * \text { LONG_PARTNER_TENURE } \\
& +\lambda_{8} \text { PARTNER_IND_EXPERT } T_{t}+\lambda_{9} \text { RESTATE_FIRM } M_{t-1}+\lambda_{10} F_{I} \text { IRM_TENURE } \\
& +\lambda_{11} \text { LASSET }_{t}+\lambda_{12} \triangle A S S E T_{t}+\lambda_{13} A R_{-} I N_{t-1}+\lambda_{14} \text { FOREIGN }_{t-1}+\lambda_{15} \text { FINANCING }_{t-1} \\
& +\lambda_{16} L E V_{t-1}+\lambda_{17} R_{\text {ROA }} t_{t-1}+\lambda_{18} L O S S_{t-1}+\lambda_{19} S_{T} D_{-} C F O_{t}+\lambda_{20} H_{E R F_{t-1}}+\lambda_{21} L_{L S T E D} \\
& +\lambda_{22} O W N E R S H I P_{t-1}+\lambda_{23} L B O A R D \_S I Z E_{t-1}+e_{t}
\end{aligned}
$$

Where all variables are as defined earlier.

If engagement partner general, industry-specific, or client-specific experience mitigates the persistence of poor audit quality, then the coefficients on the interactions between MISSTATE_PARTNER $R_{t-1}$ and $L O N G \_P A R T N E R \_G E N \_E X P E R I E N C E_{t}, L O N G \_P A R T N E R \_I N D$ _EXPERIENCE $E_{t}$, and LONG_PARTNER_TENURE $E_{t}$ will be negative and significant, respectively.

We also test whether prior restatements are associated with current year misstatements at the engagement partner level. Here, we estimate the following logistic regression:

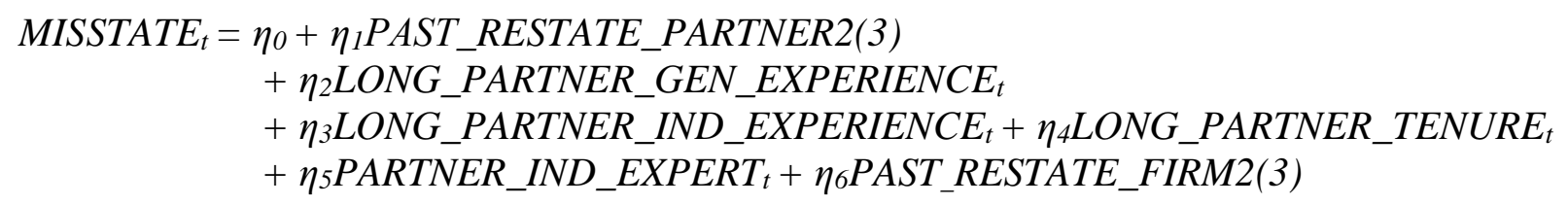




$$
\begin{aligned}
& +\eta_{7} \text { FIRM_TENURE }_{t}+\eta_{8} \text { LASSET }_{t}+\eta_{9} \triangle A S S E T_{t}+\eta_{10} \text { AR_IN } N_{t-1}+\eta_{11} \text { FOREIGN }_{t-1} \\
& +\eta_{12} \text { FINANCING }_{t-1}+\eta_{13} \text { LEV }_{t-1}+\eta_{14} \text { ROA }_{t-1}+\eta_{15} \text { LOSS }_{t-1}+\eta_{16} S T D_{-} C F O_{t} \\
& +\eta_{17} \text { HERF }_{t-1}+\eta_{18} \text { LISTED }_{t}+\eta_{19} \text { OWNERSHIP }_{t-1}+\eta_{20} L B O A R D \_S I Z E_{t-1}+e_{t}(3)
\end{aligned}
$$

Where:

PAST_RESTATE_PARTNER2(3) = an indicator variable set equal to one if the client's engagement partner was associated with at least one restatement announcement (made by another client) in the past two (or three) years, and zero otherwise;

PAST_RESTATE_FIRM2(3) = an indicator variable set equal to one if the audit firm was associated with at least one restatement announcement (made by another client) in the past two (or three) years, and zero otherwise; and

All other variables are as defined earlier.

If past restatements predict current misstatements at the engagement partner level, the coefficient on PAST_RESTATE_PARTNER2(3) will be positive and significant. ${ }^{23}$

To examine the prediction in $\mathrm{H} 2$ - that an engagement partner's likelihood of losing current audit clients and attracting new audit clients decreases if she was associated with a prioryear restatement - we modify the audit firm turnover regression model in Boone et al. (2014) as follows: ${ }^{24}$

$$
\begin{aligned}
& \text { CH_PARTNER } R_{t}=\zeta_{0}+\zeta_{1} P R E D E C E S S O R \_R E S T A T E 2(3) \\
& +\zeta_{2} S U C C E S S O R \_R E S T A T E 2(3)+\zeta_{3} L A S S E T_{t}+\zeta_{4} \Delta A S S E T_{t}+\zeta_{5} \Delta H A S S E T_{t} \\
& +\zeta_{6} A B S \_D A C C_{t}+\zeta_{7} M A O_{t}+\zeta_{8} R O A_{t}+\zeta_{9} G C_{t} \\
& +\zeta_{10} L O N G_{-} P A R T N E R \_T E N U R E_{t-1}+\zeta_{11} L O S S_{t}+\zeta_{12} L I S T E D_{t}+\zeta_{13} L E V_{t} \\
& +\zeta_{14} \Delta L E V_{t}+\zeta_{15} I N V R E C_{t}+\zeta_{16} C_{A S H}+\zeta_{17} F O R E I G N_{t}+\zeta_{18} \text { FINANCING }_{t}
\end{aligned}
$$

\footnotetext{
${ }^{23}$ In untabulated analyses, we test for, but do not find, an association between partner restatements in only the one year prior and current misstatements.

${ }^{24}$ Boone et al. (2014) use a similar model to examine whether Deloitte lost more audit clients and/or gained fewer audit clients following the PCAOB disciplinary order against it in 2007. We include the variables in Boone et al. (2014) to the extent possible but do not control for client/auditor mismatch because we require that the client does not change audit firms (and only changes engagement partners) for this test. However, we also control for the audit firm type (Big N) because Big N firms may be more likely to rotate engagement partners since they should have more partners and multiple partners with related audit expertise. We also do not control for abnormal audit fees because the audit fee data are not widely available for Taiwanese companies or for client mergers and acquisitions because TEJ does not provide these data. Finally, we supplement the Boone et al. (2014) model with include additional control variables from Equation (1).
} 


$$
\begin{aligned}
& +\zeta_{19} O \mathrm{OWNERSHIP}_{t}+\zeta_{20} \mathrm{FIRMTENURE}_{t}+\zeta_{21} L B O A R D \_S I Z E_{t}+\zeta_{22} S T D_{-} \mathrm{CFO}_{t} \\
& +\zeta_{23} \mathrm{HERF}_{t}+\zeta_{24} \mathrm{Big}_{t}+e_{t}
\end{aligned}
$$

Where:

CH_PARTNER $\quad=$ an indicator variable set equal to one if the year $t$ engagement partner (i.e., the successor auditor) is different from the year $t-1$ engagement partner (i.e., the predecessor auditor);

PREDECESSOR_RESTATE2(3) = an indicator variable set equal to one if least one of the predecessor engagement partner's clients disclosed a restatement in the two (three) years preceding the partner change, and zero otherwise;

SUCCESSOR_RESTATE2(3) = an indicator variable set equal to one if least one of the successor engagement partner's clients disclosed a restatement in the two (three) years preceding the partner change year, and zero otherwise;

$A B S \_D A C C_{t} \quad$ = the absolute value of performance-adjusted discretionary accruals;

$M A O_{t} \quad=$ an indicator variable set equal to one if the company receives a modified audit opinion other than for going concern reasons, and zero otherwise;

$G C_{t} \quad=$ an indicator variable set equal to one if the company receives a going concern audit opinion, and zero otherwise;

${I N V R E C_{t}}_{=}=$the ratio of the sum of inventory and accounts receivable to total assets;

$\mathrm{CASH}_{t} \quad$ = the ratio of cash to total assets;

$\operatorname{Big} N_{t} \quad$ = indicator variable set equal one if the audit firm belongs to the Big N, and zero otherwise; and

All other variables are as previously defined.

We begin with the sample used to estimate Equation (1) but we exclude client-year turnover observations that are likely to be unrelated to partner-level audit quality. These include engagement partner turnovers due to mandatory partner rotation, turnovers where the original engagement partner rotates back to the client within two years, and changes where the order of 
the engagement partner signatures reverses (so that the first signing partner becomes the second signing partner but does not leave the engagement). ${ }^{25} \mathrm{We}$ also exclude any observations where the audit firm (rather than just the engagement partner) changed because we want to capture the reputational effects of restatements on engagement partners as opposed to cases where the client changes audit firms because of other pressures (e.g., audit fees). To avoid confounding the reputational effects of past restatements (made by other clients) with potential disagreements related to current company-specific restatements, we also exclude observations that report a restatement in year $t$. If a reputation for past restatements reduces engagement partners' ability to retain current clients and/or to attract new clients, the coefficient on PREDECESSOR _RESTATE2(3) will be positive and significant and the coefficient on SUCCESSOR _RESTATE2(3) will be negative and significant.

\section{SAMPLE DESCRIPTION AND EMPIRICAL RESULTS}

\subsection{Sample Description}

We obtain all non-financial observations from the TEJ database for the years 1996 through 2010. Our sample period starts in 1996 because the TEJ database provide coverage of a relatively stable sample of companies starting in this year and because some of the control variables used in our study are not available before 1996. For tests of H1, we restrict our sample to companies whose engagement partners audit at least three clients in the current year. When estimating Equations (1), (2), and (3), we also omit clients that have misstated in the preceding three years so that any results cannot be attributed to client-specific financial reporting quality. This results in a sample comprised of 13,505 company-year observations for the estimation of Equations (1) through (3). For tests of H2, our sample consists of 12,174 company-year

\footnotetext{
${ }^{25}$ Our inferences are robust, however, if we do not exclude partner changes arising from changes in the order of the engagement partner signatures.
} 
observations; we lose additional observations in these partner turnover tests because we exclude any observations where 1) the signing partner "rotates back" within two years after a signing partner change occurs, 2) the first signing partner becomes the second signing partner, and 3) the audit firm changes.

Table 1 presents descriptive statistics for the sample we use to test H1. On average, one percent of companies in Taiwan report misstatements of their financial statements in a given year. Thirteen (13) percent of engagement partners had at least one client misstate in the prior year and 79 percent of audit firms had at least one client restate in the prior year and. Four (4) percent of engagement partners are industry experts. Untabulated statistics reveal that partner general audit experience ranges from 3 to 23 years, with a sample mean of 12 years, partner industry experience ranges from 1 to 20 years, with a sample mean of 9.76 years, and partner client-specific experience (tenure) ranges from 1 to 17 years, with a sample mean of 5.75 years. Audit firm tenure ranges from 1 to 24 years, with a sample mean of 9.21 years.

\subsection{Empirical Results}

Table 2 presents correlations between selected key variables. MISSTATE_PARTNER $R_{t-1}$ is positively correlated with $\operatorname{MISSTATE}_{t}(\rho=0.03)$, suggesting that when a partner's other clients have misstated in the past year, it is more likely that her current clients will misstate. We do not find a significant correlation, however, between misstatements in year $t-1$ at the audit firm level and year $t$ misstatements at the client level. ${ }^{26}$

To determine whether misstatements are persistent at the engagement partner level (i.e., if past client misstatements (made by other clients) increase the likelihood of current client

\footnotetext{
${ }^{26}$ Untabulated analyses reveal that the correlations among control variables not included in this table are consistent with expectations. For example, client size is positively and significantly correlated with listing status $(\rho=0.42)$, audit firm tenure $(\rho=0.41)$, and board size $(\rho=0.32)$. To provide assurance that mulitcollinearity does not affect our inferences, we calculate variance inflation factors (VIFs) and find that all VIFs are below 2.5.
} 
misstatements), in Table 3, we present the results from estimating Equation (1). The coefficient on MISSTATE_PARTNER $R_{t-1}$ is positive and statistically significant (p-value $=0.07$ ), confirming the univariate result in Table 2 - the likelihood that a current client misstates is significantly higher when at least one of its engagement partner's other clients misstated in the prior year. In addition, the effect is economically important; holding all the other independent variables at their means, the probability of a current client misstating is 13.28 percent greater when at least one of its engagement partner's other clients misstated in the prior year (relative to when none of its engagement partner's other clients misstated in the prior year). ${ }^{27}$ The coefficient on MISSTATE_FIRM is insignificant (p-value $=0.86$ ), suggesting that our results are not driven by prior misstatements occurring at the audit firm (but not engagement partner) level.

In Table 4, we examine whether the persistence of misstatements at the engagement partner level varies with engagement partner general audit experience, industry-specific experience, and/or firm-specific experience (tenure). Because these measures can be highly correlated, we estimate the model with each individual interaction and then with all of the interactions in the model. In Column 1, we find a negative and significant coefficient on MISSTATE_PARTNER*LONG_PARTNER_GEN_EXPERIENCE (p-value $=0.01)$, suggesting that when engagement partners have more years of audit experience, the likelihood that their other clients misstate in the year subsequent to an initial client misstatement (i.e., that misstatements are persistent) is lower. Similarly, in Column 2, we find a negative and significant coefficient on MISSTATE_PARTNER* LONG_PARTNER_IND_EXPERIENCE (p-value = 0.07), suggesting that when engagement partners have more years of audit experience in a given industry, the likelihood that their clients in that industry misstate following another client's prior

\footnotetext{
${ }^{27}$ We used the MARGINS, AT MEANS command in STATA to derive this estimate.
} 
year misstatement is lower. However, in Column 3, we find no evidence that an engagement partners' client-specific experience (tenure) has an impact on the relation between prior misstatements made by other clients and current client misstatements because the coefficient on MISSTATE_PARTNER *LONG_PARTNER_TENURE is not significantly different from zero (pvalue $=0.78$ ). Finally, when we estimate the full model in Column 4 , we find that only the coefficient on MISSTATE_PARTNER*LONG_PARTNER_GEN_EXPERIENCE is significantly negative ( $\mathrm{p}$-value $=0.04)$, suggesting that an engagement partner's level of general audit experience is most important for preventing routine client misstatements.

Because of issues raised in Ai and Norton (2003) regarding the interpretation of interaction effects in nonlinear models, in Figures 1 through 3, we present plots of the z-statistics for the individual interaction terms MISSTATE_PARTNER*LONG_PARTNER_GEN_ EXPERIENCE, MISSTATE_PARTNER*LONG_PARTNER_IND_EXPERIENCE, and MISSTATE_PARTNER*LONG_PARTNER_TENURE from the Table 4 models. ${ }^{28}$ In Figures 1 through 3 , the distributions of z-statistics are consistently negative, supporting the notion that experience reduces the persistence of partner misstatements. Moreover, in Figure 1, the average z-statistic for general audit experience is -1.56 ( $p$-value $=0.06$ ), suggesting that the engagement partner's general audit experience is an important determinant of the persistence of client misstatements. However, the average $\mathrm{z}$-statistic for industry experience is -1.25 ( $\mathrm{p}$-value $=0.11$ ), confirming that the effect of an engagement partner's industry-specific audit experience on the persistence of client misstatements is weak at best. Finally, with respect to client-specific experience, the average $\mathrm{z}$-statistic is $-0.25(\mathrm{p}$-value $=0.40)$, suggesting that an engagement partner's client-specific experience does not affect the persistence of misstatements.

\footnotetext{
${ }^{28}$ We do not plot the distributions where all three interactions are included in the model because the INTEFF procedure in STATA does not account for multiple interactions in LOGIT models.
} 
Overall, the regression results and graphical analyses support the contention that an engagement partner's general audit experience is an important determinant of audit quality. This is consistent with prior literature which finds that experience in an area increases knowledge and improves the quality of subsequent performance in judgment tasks in related areas (Hammersley 2006).

In Table 5, we find that an engagement partner's history of past restatements predict current misstatements at the engagement partner level (i.e., the coefficients on PAST_RESTATE_PARTNER2(3) are positive and significant (p-values $=0.00$ in both specifications)). This is important because it demonstrates that investors can use an engagement partner's reputation for past financial reporting quality that is available from previously disclosed misstatements to draw inferences about current financial reporting quality. ${ }^{29}$

Finally, we examine whether prior client restatements result in the engagement partner losing audit clients and/or failing to attract new audit clients. In Panel A of Table 6, we first summarize descriptive statistics for the sample used to estimate Equation (5). Approximately 13 percent of our client-year observations change engagement partners, and 18 (23) percent of predecessor engagement partners and 17 (23) percent of successor engagement partners were associated with a restatement in the preceding two (three) years.

We provide results from estimating Equation (5) in Panel B. The coefficients on PREDECESSOR_RESTATE2 and PREDECESSOR_RESTATE3 are positive and significant (pvalues $<0.00$ ), indicating that engagement partners are more likely to lose clients when misstatements made by other audit clients are revealed in the preceding two (three) years. In

\footnotetext{
${ }^{29}$ Note that untabulated analyses reveal that considering only the immediately prior year does not allow us to draw this inference. This suggests that although partner-level restatements do not occur in each and every year, information about an engagement partner's performance over multiple years can nonetheless be valuable.
} 
addition, the coefficients on SUCCESSOR_RESTATE3 are negative and significant (p-values < 0.00 ), indicating that auditors with a past history of restatements are less likely to attract new clients.

Overall, the results from our multivariate tests suggest that audit clients do obtain valuable information from partner name disclosures and make auditor engagement decisions based on information about past audit quality at the engagement partner level.

\section{CONCLUSION}

In this study, we examine the association between an engagement partner's reputation for past audit failures and actual and perceived audit quality using a sample of audit engagements from Taiwan, where engagement partner names are disclosed. Our study is timely because in November 2014, the PCAOB indicated that their proposed engagement partner name disclosure standard could be finalized soon. ${ }^{30}$

We find that the likelihood of an engagement partner's current client misstating its financial statements is greater when at least one of the engagement partner's other clients misstated in the prior year. Analyses related to auditor experience reveal that misstatements are less persistent when engagement partners have more general auditing experience (and in some specifications, more industry-specific experience), but client-specific experience does not impact the persistence of misstatements. These findings are important because they confirm the notion that the individual engagement partner plays an important role in determining the quality of audit services and reveals that audit quality is persistent at the audit partner level.

\footnotetext{
${ }^{30}$ See "PCAOB may soon require naming of engagement partner" in the Journal of Accountancy (November 25, 2014), available at: http://www.journalofaccountancy.com/news/2014/nov/pcaob-may-require-naming-engagementpartner-201411417.html.
} 
We also find that when restatements are issued by an engagement partner's clients in the prior two or three years, the likelihood that her other clients will misstate in the current year is greater. In addition, we find that engagement partners are more likely to lose current clients and less likely to acquire new clients following client restatements. These findings suggest that stakeholders can gain valuable information from engagement partner identification and they appear to use the information to form impressions of audit quality. This evidence should be germane to the PCAOB's call for research that contributes to the ongoing debate about whether disclosure of engagement partner names can provide information that is useful for market participants.

The PCAOB has been criticized by the Securities and Exchange Commission for not pursuing more technical auditing standard setting activities and focusing more on "trying to overhaul and set policy for the accounting industry."31 The PCAOB's work on engagement partner name disclosure is cited as an example of this focus on policy making. The findings in our study suggest that the PCAOB's standard setting activities related to partner name disclosure in the U.S. could provide valuable economic information to market participants. Overall, our results support the notion that investors and audit clients can benefit from engagement partner name disclosure but a limitation of our study is that we cannot measure the potential costs associated with such a disclosure.

\footnotetext{
${ }^{31}$ See "SEC: Accounting Board Is Dragging Feet" in the Wall Street Journal (December 14, 2014), available at: http://www.wsj.com/articles/sec-accounting-board-is-dragging-feet-1418605107?KEYWORDS=pcaob.
} 


\section{REFERENCES}

Abbott, L., K. Gunny, and T. Zhang. 2013. When the PCAOB talks, who listens? Evidence from stakeholder reaction to GAAP-deficient PCAOB inspection reports of small auditors. Auditing: Journal of Practice and Theory 32 (1): 1-31.

Ai, C., and E. C. Norton. 2003. Interaction terms in logit and probit models. Economics Letters 80 (1): 123-129.

Bamber, L., J. Jiang, and I. Wang. 2010. What's my style? The influence of top managers on voluntary corporate financial disclosure. The Accounting Review 85 (4): 1131-1162.

Blouin, J., B. Grey, and B. Rountree. 2007. An analysis of forced auditor change: The case of former Arthur Andersen clients. The Accounting Review 82 (3): 621-650.

Boone, J. P., I. K. Khurana, and K. K. Raman. 2014. Did the 2007 PCAOB disciplinary order against Deloitte impose actual costs on the firm or improve its audit quality? The Accounting Review (Forthcoming).

Brown, C. E., M. E. Peecher, and I. Solomon. 1999. Auditors' hypothesis testing in diagnostic inference tasks. Journal of Accounting Research 37 (1): 1-26.

Cao, Y., L. A. Myers, and T. C. Omer. 2012. Does company reputation matter for financial reporting quality? Evidence from restatements. Contemporary Accounting Research 29 (3): 956-990.

Carcello, J., and C. Li. 2013. Costs and benefits of requiring an engagement partner signature: Recent experience in the United Kingdom. The Accounting Review 88 (5): 1511-1546.

Carey, P., and R. Simnett. 2006. Audit partner tenure and audit quality. The Accounting Review 81 (3): 653-676.

Chakravarthy, J., E. deHaan, and S. 2014. Reputation repair after a serious restatement. The Accounting Review 89 (4): 1329-1363.

Chen, C. Y., C. J. Lin, and Y. C. Lin. 2008. Audit partner tenure, audit firm tenure, and discretionary accruals: Does long auditor tenure impair earnings quality? Contemporary Accounting Research 25 (2): 415-445.

Chin, C., and H. Chi. 2009. Reducing restatements with increased industry experience. Contemporary Accounting Research 26 (3): 729-765.

Cohen, J., and G. Trompeter. 1998. An examination of factors affecting audit practice development. Contemporary Accounting Research 15 (4): 481-476. 
Daugherty, B., D. Dickins, and W. Tervo. 2011. Negative PCAOB inspections of triennially inspected auditors and involuntary and voluntary client losses. International Journal of Auditing 15 (3): 231-246.

Desai, H., S. Krishnamurthy, and K. Venkataraman. 2006. Do short sellers target firms with poor earnings quality? Evidence from restatements. Review of Accounting Studies 11 (1): 7190.

Feldmann, D., W. Read, and M. Abdolmohammadi. 2009. Financial restatements, audit fees, and the moderating effect of CFO turnover. Auditing: Journal of Practice and Theory 28 (1): 205-233.

Firth, M. 1990. Auditor reputation: The impact of critical reports issued by government inspectors. Rand Journal of Economics 21 (3): 374-389.

Francis, J. R. 2011. A framework for understanding and researching audit quality. Auditing: Journal of Practice and Theory 30 (2): 125-152.

., E. L. Maydew, and H. C. Sparks. 1999. The role of Big 6 auditors in the credible reporting of accruals. Auditing: A Journal of Practice and Theory 18 (2): 17-34. ., and P. Michas. 2013. The contagion effect of low-quality audits. The Accounting Review 88 (2): 521-553. , and M. Yu. 2009. The effect of Big Four office size on audit quality. The Accounting Review 84 (5): 71-97.

Ge, W., D. Matsumoto, and J. Zhang. 2011. Do CFOs have styles of their own? An empirical investigation of the effect of individual CFOs on accounting practices. Contemporary Accounting Research 28 (4): 1141-1179.

Gow, I., G. Ormazabal, and D. Taylor. 2010. Correcting for cross-sectional and time-series dependence in accounting research. The Accounting Review 85 (2), 483-512.

Gramling, A. A. 1999. External auditors' reliance on work performed by internal auditors: The influence of fee pressure on this reliance decision. Auditing: A Journal of Practice $\&$ Theory 18 (Supplement): 117-135.

Hammersley, J. S. 2006. Pattern identification and industry-specialist auditors. The Accounting Review 60 (2): 309-336.

Hennes, K. M., A. J. Leone, and B. P. Miller. 2014. Determinants and market consequences of auditor dismissals after accounting restatements. The Accounting Review 89 (3): 10511082. 
Hilary, G., and C. Lennox. 2005. The credibility of self-regulation: Evidence from the accounting profession's peer review program. Journal of Accounting and Economics 40 (1): 211-229.

Hribar, P., and N. Jenkins. 2004. The effect of accounting restatements on earnings revisions and the estimated cost of capital. Review of Accounting Studies 9 (2-3): 337-356.

Hurtt, K., M. M. Eining, and D. Plumlee. 2008. An experimental examination of professional skepticism. Working paper, Baylor University and University of Utah.

Knechel, W. R., G. Krishnan, M. Pevzner, L. Shefchik, and U. Velury. 2013. Audit quality indicators: Insights from academic literature. Auditing: Journal of Practice and Theory 32 (Supplement 1): 385-421.

, L. Nielmi, and M. Zerni. 2015. Does the identity of engagement partners matter? An analysis of audit partner reporting decisions. Forthcoming, Contemporary Accounting Research.

Koch, C. 2011. The pricing of engagement partner expertise. Working paper, University of Mannheim.

Lambert, T., B. Luippold, and C. Stefaniak. 2012. Audit partner disclosure: An examination of investor reaction to negative information and potential implications for auditor independence. Working paper, University of Massachusetts at Amherst, Georgia State University, and Oklahoma State University.

Libby, R., and D. M. Frederick. 1990. Experience and the ability to explain audit findings. Journal of Accounting Research 22 (2): 348-367.

Manry, D., T. Mock, and J. Turner. 2008. Does increased audit partner tenure reduce audit quality? Journal of Accounting, Auditing, and Finance 23: 553-572.

McGuire, S. T., T. C. Omer, and N. Y. Sharp. 2012. The impact of religion on financial reporting irregularities. The Accounting Review 87 (2): 645-673.

Messier, W., V. Owhoso, and C. Rakowski. 2008. Can partners predict subordinates' abilities to predict errors. Journal of Accounting Research 46 (5): 1241-1264.

Palmrose, Z., V. Richardson, and S. Scholz. 2004. Determinants of market reactions to restatement announcements. Journal of Accounting and Economics 37 (1): 59-89.

Peytcheva, M., and P. Gillett. 2011. How partner's views influence auditor judgments. Auditing: Journal of Practice and Theory 30 (4): 285-301. 
Public Company Accounting Oversight Board (PCAOB). 2009. Concept Release on Requiring the Engagement Partner to Sign the Audit Report. Available at http://pcaobus.org/ Rules/Rulemaking/Docket029/2009-07-28_Release_No_2009-005.pdf.

Reynolds, K., and J. R. Francis. 2000. Does size matter? The influence of large clients on officelevel auditor reporting decisions. Journal of Accounting and Economics 30 (3): 375-400.

Skinner, D., and S. Srinivasan. 2012. Audit quality and auditor reputation: Evidence from Japan. The Accounting Review 87 (5): 1737-1766.

Squires, S., S. Smith, L. McDougall, and W. Yeack. 2003. Inside Arthur Andersen: Shifting Values, Unexpected Consequences. FT Press.

Texas CPA Society (TSCPA). 2011. RE: Improving the Transparency of Audits: Proposed Amendments to PCAOB Auditing Standards and Form 2. Available at: http://www.accountingtoday.com/news/TSCPAletterPCAOBImprovingTransparencyinA udits.php.

Trompeter, G. 1994. The effect of partner compensation schemes and Generally Accepted Accounting Principles on audit partner judgment. Auditing: Journal of Practice and Theory 13 (2): 56-68.

Weber, J., M. Willenborg, and J. Zhang. 2008. Does auditor reputation matter? The case of KPMG Germany and ComROAD AG. Journal of Accounting Research 46 (4): 941-972.

Whited, R. 2013. Are 'contaminated' offices quarantined? An examination of the economic consequences of low quality audits. Working paper, University of Massachusetts Amherst.

Wilson, T. E., and R. A. Grimlund. 1990. An examination of the importance of an auditor's reputation. Auditing: A Journal of Practice \& Theory 9 (2):43-59.

Woods, A. 2011. Monitoring the monitor: When do higher-level reviewers adjust supervisors' subjective performance evaluations of internal audit employees? Working paper, College of William and Mary. 


\section{Appendix Variable Definitions}

$\triangle A S S E T$

ABS_DACC

AR_IN

Big N

$\mathrm{CASH}$

CH_PARTNER

FINANCING

FIRM_TENURE

FOREIGN

$G C$

HERF

INVREC

LASSET

LBOARD_SIZE
$=$ the percentage change in total assets during the year, to proxy for growth

$=$ the absolute value of performance-adjusted discretionary accruals

$=$ the sum of accounts receivable and inventory deflated by total assets

$=$ an indicator variable set equal one if the audit firm belongs to the Big N, and zero otherwise

$=$ the ratio of cash to total assets

$=$ an indicator variable set equal to one if the year $t$ engagement partner (i.e., the successor auditor) is different from the year $t-1$ engagement partner (i.e., the predecessor auditor), and zero otherwise

$=$ an indicator variable set equal to one if the number of shares outstanding increases by at least 10 percent or if the value of long-term debt increases by at least 20 percent during the year, and zero otherwise (following Cao et al. (2012)

$=$ the length of the audit firm-client relationship to date

$=$ the proportion of company sales generated in foreign countries, to proxy for a complexity

= an indicator variable set equal to one if the company receives a going concern audit opinion, and zero otherwise

= industry concentration, measured using the Herfindahl index

$=$ the ratio of the sum of inventory and accounts receivable to total assets

$=$ the natural log of total assets, to proxy for company size

$=$ the natural $\log$ of board size 
LISTED

LONG_PARTNER GEN_EXPERIENCE

LONG_PARTNER_ IND_EXPERIENCE

LONG_PARTNER_TENURE

LOSS

$M A O$

MISSTATE

MISSTATE_FIRM

MISSTATE_PARTNER

OWNERSHIP
$=$ leverage, measured as the ratio of total debt to total assets

$=$ an indicator variable set equal to one if the company is listed on a stock exchange, and zero otherwise

$=$ an indicator variable set equal to one if the engagement partner's general audit experience to date exceeds the sample mean, and zero otherwise, where general audit experience is measured as number of years since the partner was first identified in the TEJ database

$=$ an indicator variable set equal to one if the engagement partner's industry experience to date exceeds the sample mean, and zero otherwise, where industry experience is measured as number of years that the partner has audited clients in the given 2-digit TEJ code industry

$=$ an indicator variable set equal to one if the engagement partner's client tenure to date exceeds the sample mean, and zero otherwise, where client tenure is defined as the length of the engagement partner-client relationship

$=$ an indicator variable set equal to one if the company reports negative net income in the year, and zero otherwise

$=$ an indicator variable set equal to one if the company receives a modified audit opinion other than for going concern reasons, and zero otherwise

$=$ an indicator variable set equal to one if the current year's annual financial statements are misstated, and zero otherwise

$=$ an indicator variable set equal to one if the audit firm was associated with at least one misstatement (made by another client) in the prior year, and zero otherwise

$=$ an indicator variable set to equal one if the client's engagement partner was associated with at least one misstatement (made by another client) in the past year, and zero otherwise

$=$ the percentage of common stock owned by insiders, where insiders are defined as managers, directors, and members of the supervisory board 
PARTNER_IND_EXPERT

PAST_RESTATE_FIRM2(3)

PAST_RESTATE_PARTNER2(3)

PREDECESSOR_RESTATE2(3)

$R O A$

STD_CFO

SUCCESSOR_RESTATE2(3)
$=$ an indicator variable set equal to one if the engagement partner is an industry expert, and zero otherwise, where an industry expert is defined as the engagement partner with the largest number of clients in the 2-digit TEJ code industry (following Chin and Chi (2009))

$=$ an indicator variable set equal to one if the audit firm was associated with at least one restatement announcement (made by another client) in the past two (or three) years, and zero otherwise

$=$ an indicator variable set equal to one if the client's engagement partner was associated with at least one restatement announcement (made by another client) in the past two (or three) years, and zero otherwise

$=$ an indicator variable set equal to one if least one of the predecessor engagement partner's clients disclosed a restatement in the two (three) years preceding the partner change, and zero otherwise

$=$ return on assets (i.e., net income divided by average total assets), to proxy for company profitability

$=$ the standard deviation of operating cash flows over the prior four years

$=$ an indicator variable set equal to one if least one of the successor engagement partner's clients disclosed a restatement in the two (three) years preceding the partner change year, and zero otherwise 
Figure 1: Distribution of z-Statistics for the Interaction Term MISSTATE_PARTNER ${ }_{t-1} * L O N G \_P A R T N E R \_G E N \_E X P E R I E N C E_{t}$

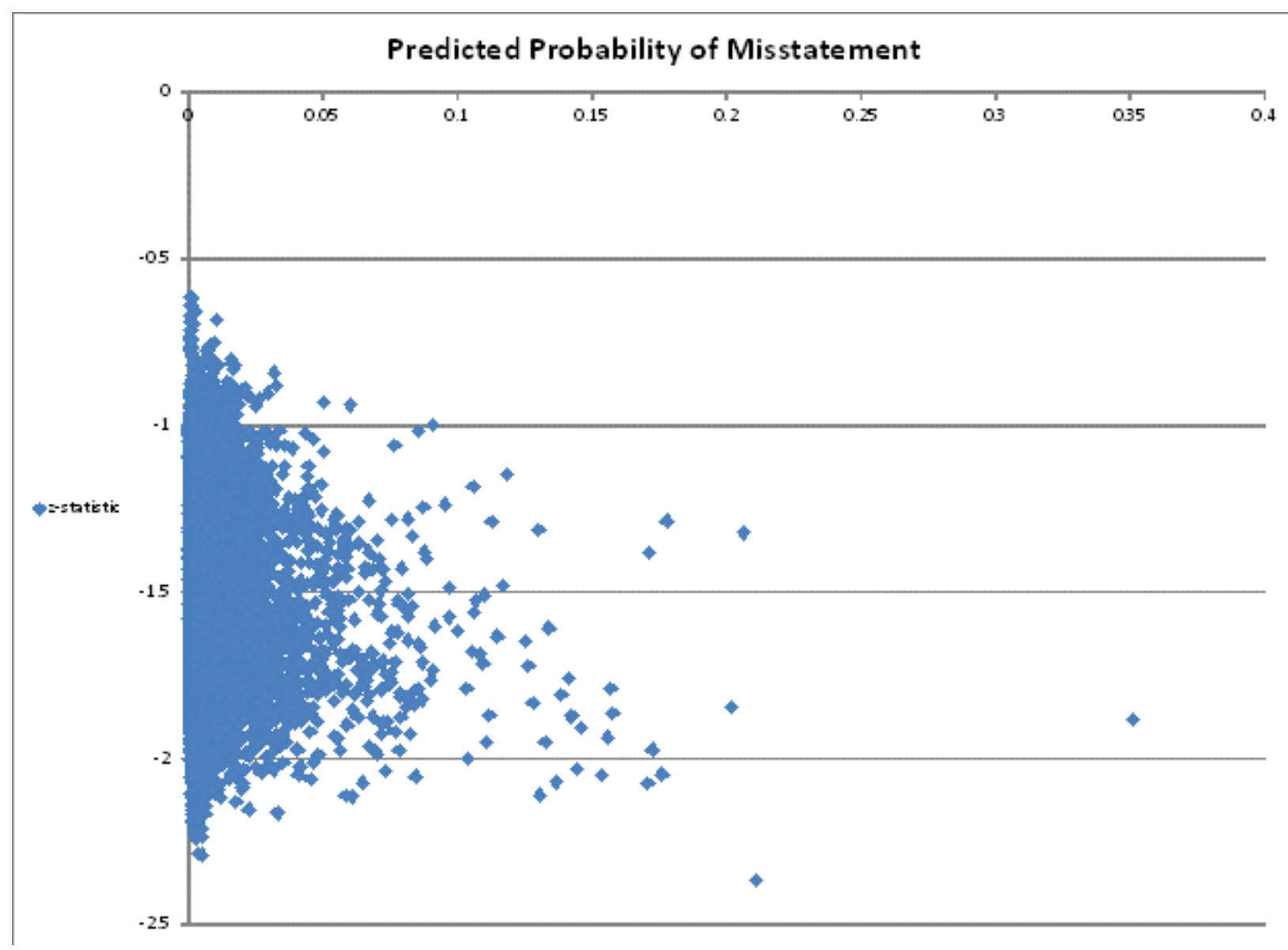


Figure 2: Distribution of z-Statistics for the Interaction Term MISSTATE_PARTNER $R_{t-1} * L O N G \_P A R T N E R \_I N D \_E X P E R I E N C E_{t}$

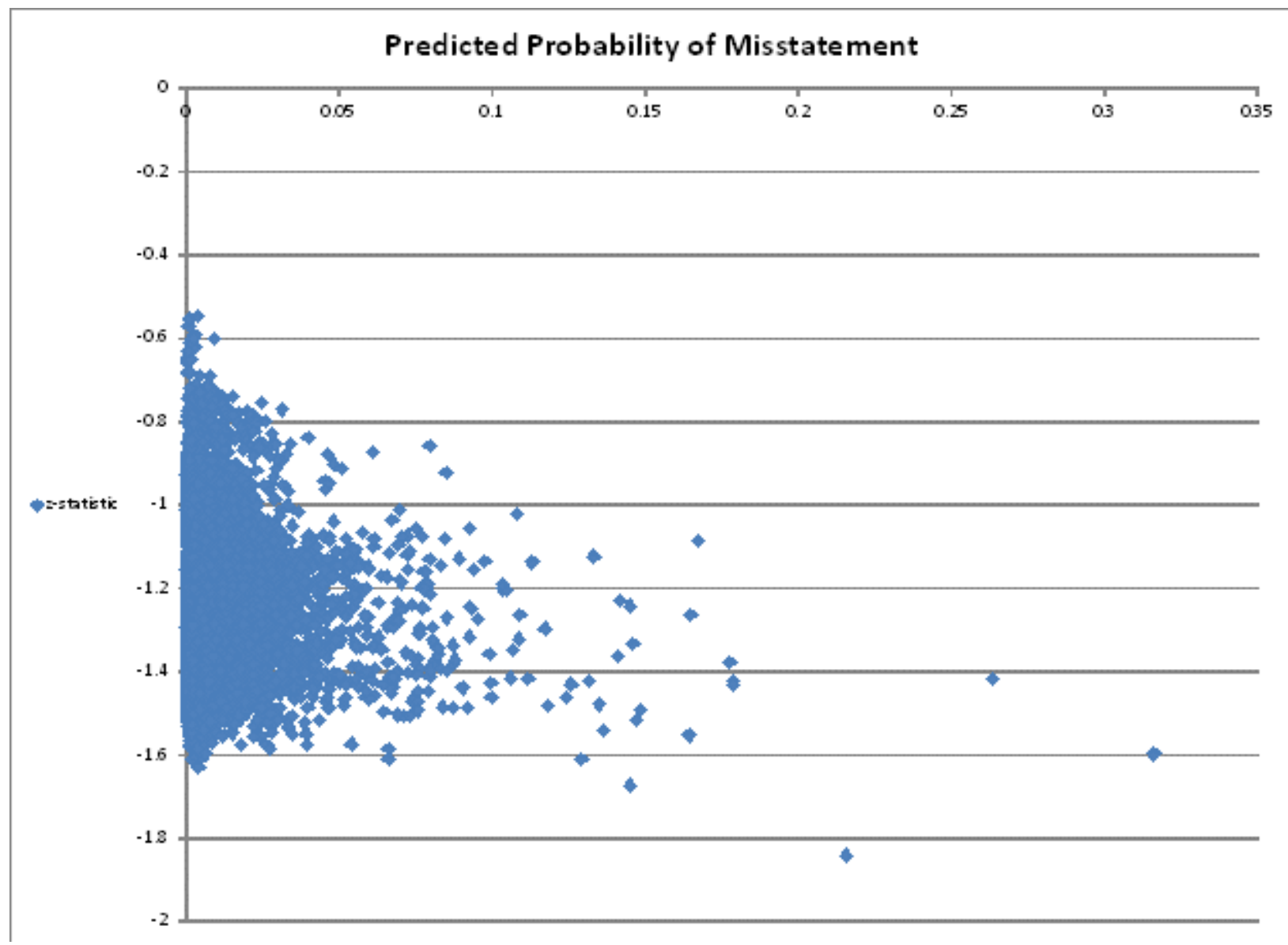


Figure 3: Distribution of z-Statistics for the Interaction Term MISSTATE_PARTNER t- $^{*}$ *LONG_PARTNER_TENURE ${ }_{t}$

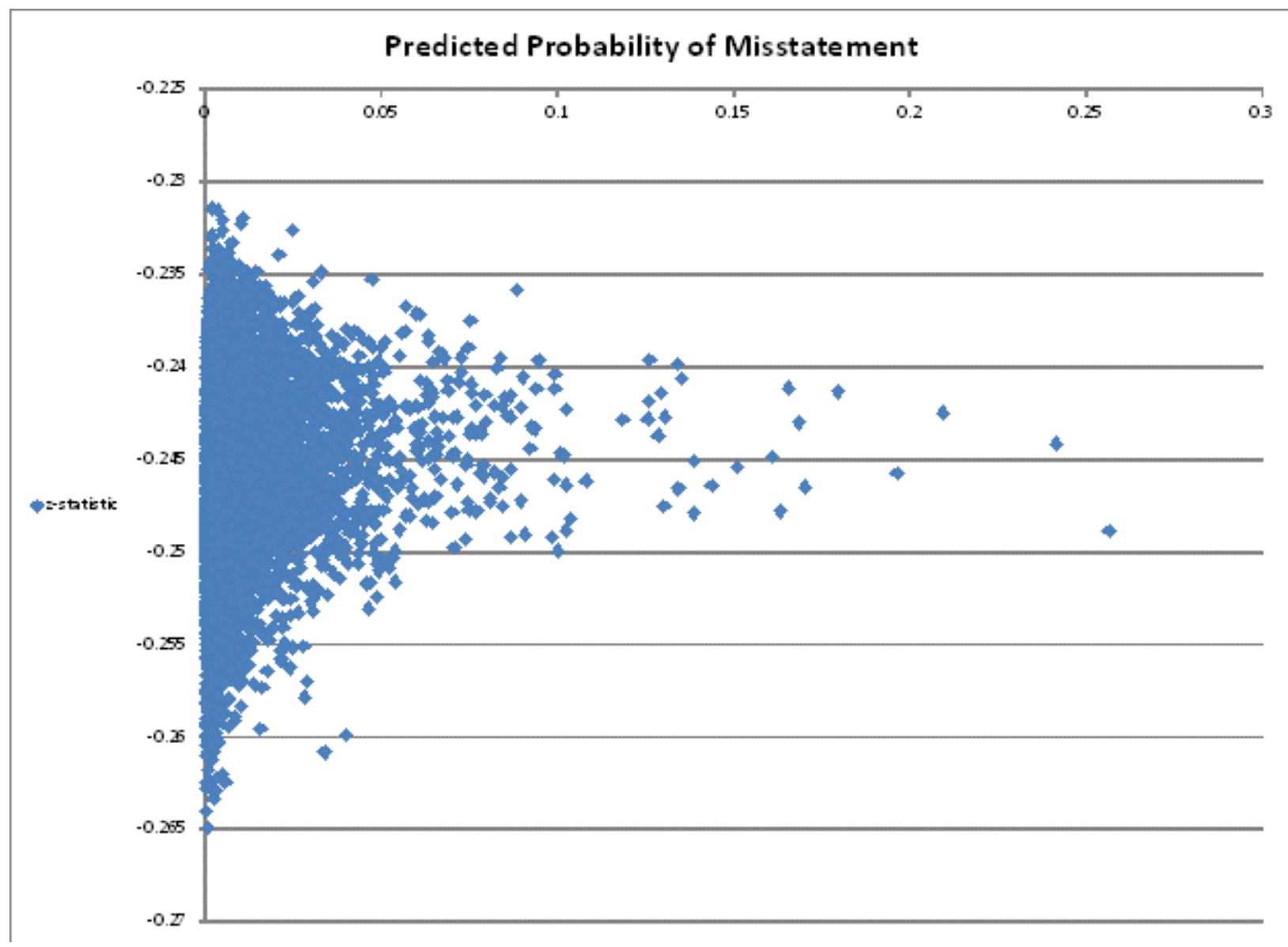


Table 1

Descriptive Statistics ( $\mathbf{N}=\mathbf{1 3 , 5 0 5})$

\begin{tabular}{|c|c|c|c|c|c|c|c|}
\hline VARIABLES & MEAN & STD & Q1 & MED & Q3 & MIN & MAX \\
\hline $\begin{array}{l}\text { MISSTATE } \\
\left(\operatorname{Prob}(M I S S T A T E=1)_{\mathrm{t}}\right)\end{array}$ & 0.01 & 0.08 & 0.00 & 0.00 & 0.00 & 0.00 & 1.00 \\
\hline MISSTATE_PARTNER $R_{t-1}$ & 0.13 & 0.34 & 0.00 & 0.00 & 0.00 & 0.00 & 1.00 \\
\hline MISSTATE_FIRM $M_{t-1}$ & 0.79 & 0.40 & 1.00 & 1.00 & 1.00 & 0.00 & 1.00 \\
\hline PARTNER_IND_EXPERT $T_{t}$ & 0.04 & 0.19 & 0.00 & 0.00 & 0.00 & 0.00 & 1.00 \\
\hline $\begin{array}{l}\text { LONG_PARTNER_GEN } \\
\text { EXPERIENCE } E_{t}\end{array}$ & 0.46 & 0.49 & 0.00 & 0.00 & 1.00 & 0.00 & 1.00 \\
\hline $\begin{array}{l}\text { LONG_PARTNER_IND } \\
\text { EXPERIENCE } E_{t}\end{array}$ & 0.50 & 0.50 & 0.00 & 0.00 & 1.00 & 0.00 & 1.00 \\
\hline$L O N G \_P A R T N E R \_T E N U R E_{t}$ & 0.44 & 0.50 & 0.00 & 0.00 & 1.00 & 0.00 & 1.00 \\
\hline$F I R M_{-} T E N U R E_{t}$ & 9.21 & 5.28 & 5.00 & 8.00 & 12.00 & 1.00 & 24.00 \\
\hline $\operatorname{LASSET}_{t}$ & 14.88 & 1.31 & 13.92 & 14.74 & 15.66 & 12.39 & 18.77 \\
\hline$\triangle A S S E T_{t}$ & 0.14 & 0.29 & -0.03 & 0.07 & 0.22 & -0.37 & 1.47 \\
\hline$A R \_I N_{t-1}$ & 0.32 & 0.19 & 0.18 & 0.29 & 0.43 & 0.00 & 0.97 \\
\hline FOREIGN $N_{t-1}$ & 0.45 & 0.36 & 0.06 & 0.44 & 0.79 & 0.00 & 1.00 \\
\hline FINANCING $_{t-1}$ & 0.38 & 0.49 & 0.00 & 0.00 & 1.00 & 0.00 & 1.00 \\
\hline$L E V_{t-1}$ & 0.39 & 0.17 & 0.27 & 0.39 & 0.51 & 0.07 & 0.88 \\
\hline$R O A_{t-1}$ & 0.04 & 0.11 & 0.00 & 0.05 & 0.10 & -0.38 & 0.30 \\
\hline $\operatorname{LOSS}_{t-1}$ & 0.23 & 0.42 & 0.00 & 0.00 & 0.00 & 0.00 & 1.00 \\
\hline$S T D \_C F O_{t}$ & 0.12 & 0.12 & 0.05 & 0.08 & 0.14 & 0.01 & 0.75 \\
\hline$H E R F_{t-1}$ & 0.06 & 0.07 & 0.02 & 0.03 & 0.06 & 0.01 & 0.38 \\
\hline LISTED $_{t}$ & 0.73 & 0.44 & 0.00 & 1.00 & 1.00 & 0.00 & 1.00 \\
\hline$O W N E R S H I P_{t-1}$ & 0.30 & 0.17 & 0.17 & 0.27 & 0.40 & 0.00 & 1.00 \\
\hline LBOARD_SIZE $E_{t-1}$ & 1.99 & 0.29 & 1.79 & 2.08 & 2.08 & 1.39 & 3.00 \\
\hline
\end{tabular}

See the Appendix for variable definitions. 
Table 2

Pearson Correlation Matrix

\begin{tabular}{|c|c|c|c|c|c|c|c|c|c|c|}
\hline & & 1 & 2 & 3 & 4 & 5 & 6 & 7 & 8 & 9 \\
\hline MISSTATE $\left(\operatorname{Prob}(\text { MISSTATE }=1)_{\mathrm{t}}\right)$ & 1 & - & & & & & & & & \\
\hline$M I S S T A T E \_P A R T N E R_{t-1}$ & 2 & 0.03 & - & & & & & & & \\
\hline LONG_PARTNER_GEN_EXPERIENCE $E_{t}$ & 3 & 0.00 & 0.07 & - & & & & & & \\
\hline LONG_PARTNER_IND_EXPERIENCE $E_{t}$ & 4 & 0.00 & 0.05 & 0.59 & - & & & & & \\
\hline$L O N G \_P A R T N E R \_T E N U R E_{t}$ & 5 & 0.00 & 0.02 & 0.31 & 0.35 & - & & & & \\
\hline PARTNER_IND_EXPERT & 6 & 0.00 & 0.09 & 0.02 & 0.03 & 0.01 & - & & & \\
\hline MISSTATE_FIRM $M_{t-1}$ & 7 & 0.00 & 0.11 & -0.01 & -0.01 & -0.03 & 0.04 & - & & \\
\hline FIRM_TENURE ${ }_{t}$ & 8 & 0.00 & -0.07 & 0.10 & 0.13 & 0.37 & 0.08 & -0.08 & - & \\
\hline $\operatorname{LASSET}_{t}$ & 9 & 0.04 & 0.02 & 0.06 & 0.05 & 0.14 & 0.15 & 0.00 & 0.41 & - \\
\hline$R O A_{t-1}$ & 10 & -0.05 & -0.01 & -0.02 & 0.00 & -0.02 & 0.00 & $\mathbf{0 . 0 3}$ & -0.06 & 0.04 \\
\hline
\end{tabular}

The table summarizes Pearson correlations for the selected key variables in our analyses. Correlations that are significant at $p$-value $<0.05$ are bolded. See the Appendix for variable definitions 
Table 3

The Persistence of Misstatements at the Engagement Partner Level

$\underline{\text { Dependent variable }=\operatorname{Prob}(\text { MISSTATE }=1)_{\mathrm{t}}}$

\begin{tabular}{|c|c|c|}
\hline & $\begin{array}{c}\text { Coefficient } \\
\text { Estimate } \\
\end{array}$ & p-value \\
\hline Intercept & $-7.78 * * *$ & 0.00 \\
\hline MISSTATE_PARTNER $R_{t-1}$ & $0.56 *$ & 0.07 \\
\hline$L O N G \_P A R T N E R \_G E N \_E X P E R I E N C E_{t}$ & -0.24 & 0.50 \\
\hline$L O N G \_P A R T N E R \_I N D \_E X P E R I E N C E_{t}$ & 0.39 & 0.29 \\
\hline$L O N G \_P A R T N E R \_T E N U R E_{t}$ & -0.02 & 0.93 \\
\hline PARTNER_IND_EXPERT & -0.97 & 0.13 \\
\hline MISSTATE_FIRMt-1 & 0.05 & 0.86 \\
\hline$F I R M \_T E N U R E_{t}$ & -0.03 & 0.25 \\
\hline LASSET $_{t}$ & $0.30 * * *$ & 0.00 \\
\hline$\triangle A S S E T_{t}$ & $0.72 * *$ & 0.04 \\
\hline$A R \_I N_{t-1}$ & $-1.07 *$ & 0.06 \\
\hline FOREIGN $N_{t-1}$ & -0.51 & 0.26 \\
\hline FINANCING $G_{t-1}$ & -0.02 & 0.85 \\
\hline$L E V_{t-1}$ & $1.99 * * *$ & 0.00 \\
\hline$R O A_{t-1}$ & -2.58 & 0.11 \\
\hline$L O S S_{t-1}$ & $0.67 * *$ & 0.03 \\
\hline$S T D \_C F O_{t}$ & $1.53 * *$ & 0.05 \\
\hline$H E R F_{t-1}$ & -4.47 & 0.36 \\
\hline LISTED $_{t}$ & 0.05 & 0.89 \\
\hline$O W N E R S H I P_{t-1}$ & -1.17 & 0.15 \\
\hline$L B O A R D \_S I Z E_{t-1}$ & -0.47 & 0.13 \\
\hline Industry fixed effects & Yes & \\
\hline $\mathrm{N}$ & 13,505 & \\
\hline Area under the ROC curve & 0.80 & \\
\hline
\end{tabular}

This table presents the results from estimating a logistic regression of the likelihood of an accounting misstatement in the current year as a function of an accounting misstatement (made by another client of the same engagement partner) in the preceding year. The sample consists of client-year observations from 1996 through 2010. Two-tailed $p$-values are based on cluster-robust standard errors (clustered by audit client and year). *,**, *** denote significance of $0.1,0.05$, and 0.01 level, respectively. See the Appendix for variable definitions. 
Table 4

The Effects of Experience on the Persistence of Misstatements

Dependent variable $=\operatorname{Prob}(\text { MISSTATE }=1)_{\mathrm{t}}$

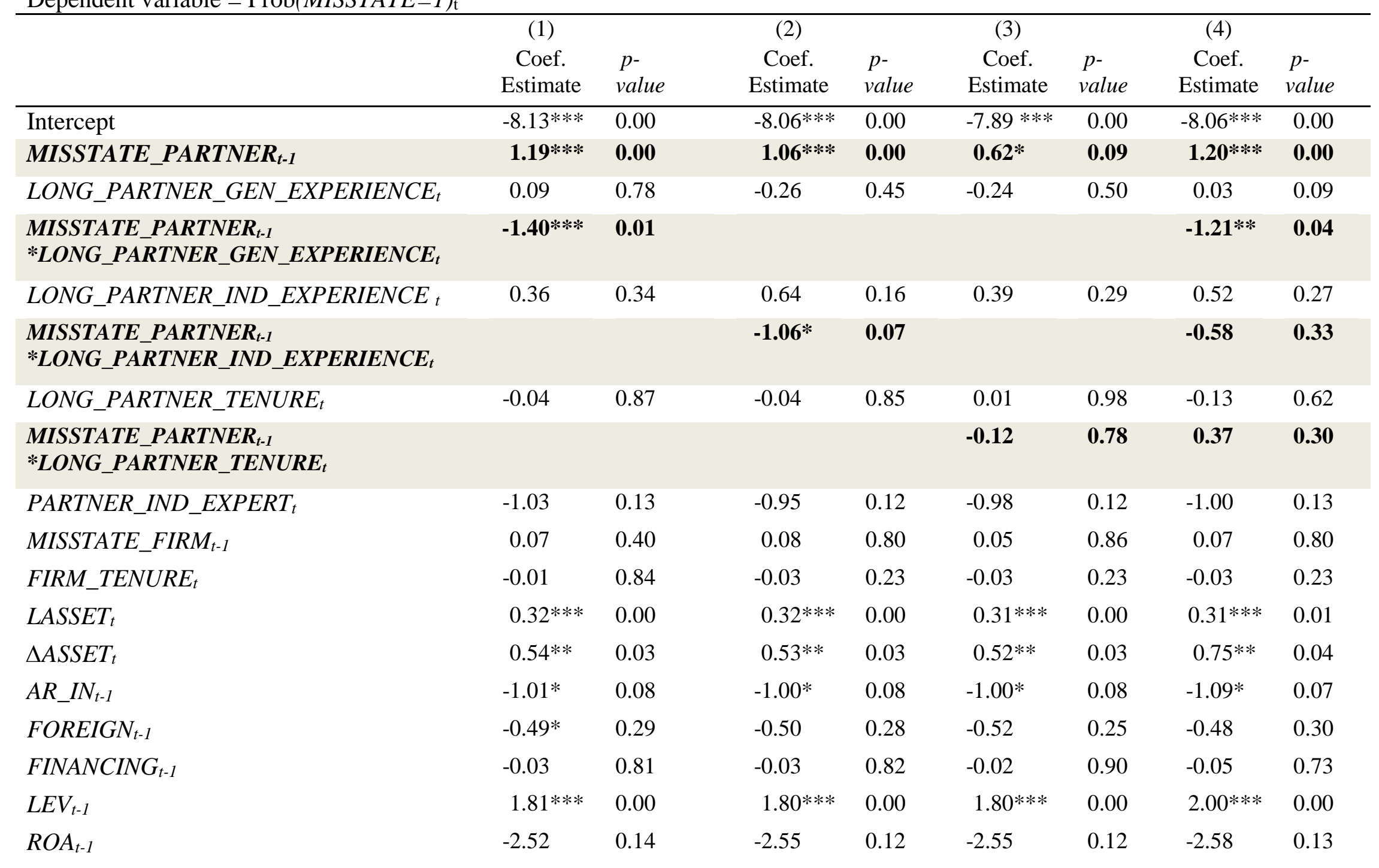




\begin{tabular}{|c|c|c|c|c|c|c|c|c|}
\hline $\operatorname{LOSS}_{t-1}$ & $0.65 * *$ & 0.04 & $0.64 * *$ & 0.05 & $0.65 * *$ & 0.05 & $0.68 * * *$ & 0.03 \\
\hline$S T D \_C F O_{t}$ & $1.30 * *$ & 0.05 & $1.51 * *$ & 0.04 & $1.35 * *$ & 0.04 & $1.45^{*}$ & 0.06 \\
\hline$H E R F_{t-1}$ & -4.50 & 0.37 & -4.32 & 0.39 & -4.27 & 0.38 & -4.68 & 0.36 \\
\hline LISTED $_{t}$ & 0.07 & 0.85 & 0.05 & 0.90 & 0.04 & 0.92 & 0.14 & 0.65 \\
\hline OWNERSHIP $P_{t-1}$ & -1.15 & 0.15 & -1.10 & 0.17 & -1.09 & 0.18 & $-1.44 * * *$ & 0.00 \\
\hline$L B O A R D \_S I Z E_{t-1}$ & -0.41 & 0.20 & -0.46 & 0.15 & -0.47 & 0.14 & -0.49 & 0.16 \\
\hline Industry fixed effects & Yes & & Yes & & Yes & & Yes & \\
\hline $\mathrm{N}$ & 13,505 & & 13,505 & & 13,505 & & 13,505 & \\
\hline Area under the ROC curve & 0.80 & & 0.80 & & 0.80 & & 0.80 & \\
\hline
\end{tabular}

This table presents the results from estimating logistic regressions investigating the effects of engagement partner experience on the probability of accounting misstatements in a particular year as a function of an accounting misstatement (made by another client of the same engagement partner) in the preceding year. The sample consists of client-year observations from 1996 through 2010. Two-tailed $p$-values are based on cluster-robust standard errors (clustered by audit client and year). * **, *** denote significance of $0.1,0.05$, and 0.01 level, respectively. See the Appendix for variable definitions. 
Table 5

Using restatements to predict future misstatements

$\underline{\text { Dependent variable }=\operatorname{Prob}(\text { MISSTATE }=1)_{\mathrm{t}}}$

\begin{tabular}{|c|c|c|c|c|}
\hline & $\begin{array}{c}\text { Coefficient } \\
\text { Estimate }\end{array}$ & $p$-value & $\begin{array}{c}\text { Coefficient } \\
\text { Estimate }\end{array}$ & $p$-value \\
\hline Intercept & -8.55 & 0.00 & -8.61 & 0.00 \\
\hline PAST_RESTATE_PARTNER2 & $0.83 * * *$ & $\mathbf{0 . 0 0}$ & & \\
\hline PAST_RESTATE_PARTNER3 & & & $0.80 * * *$ & $\mathbf{0 . 0 0}$ \\
\hline LONG_PARTNER_GEN_EXPERIENCE $E_{t}$ & -0.37 & 0.24 & -0.30 & 0.39 \\
\hline LONG_PARTNER_IND_EXPERIENCE $E_{t}$ & 0.32 & 0.39 & 0.34 & 0.37 \\
\hline$L O N G \_P A R T N E R \_T E N U R E_{t}$ & -0.10 & 0.65 & -0.08 & 0.72 \\
\hline PARTNER_IND_EXPERT $T_{t}$ & -1.03 & 0.11 & -0.97 & 0.13 \\
\hline PAST_RESTATE_FIRM2 & $0.48 *$ & 0.08 & & \\
\hline PAST_RESTATE_FIRM3 & & & 0.40 & 0.13 \\
\hline$F I R M \_T E N U R E_{t}$ & -0.02 & 0.31 & -0.03 & 0.26 \\
\hline$L_{A S S E T}$ & $0.29 * * *$ & 0.00 & $0.30 * * *$ & 0.00 \\
\hline$\triangle A S S E T_{t}$ & $0.73 * *$ & 0.04 & $0.72 * * *$ & 0.04 \\
\hline$A R \_I N_{t-1}$ & $-1.19 * *$ & 0.03 & $-1.09 * *$ & 0.04 \\
\hline FOREIGN $N_{t-1}$ & -0.49 & 0.28 & -0.48 & 0.29 \\
\hline FINANCING $_{t-1}$ & -0.02 & 0.89 & -0.03 & 0.80 \\
\hline$L E V_{t-1}$ & $2.03 * * *$ & 0.00 & $2.04 * * *$ & 0.00 \\
\hline$R O A_{t-1}$ & -2.53 & 0.14 & -2.56 & 0.14 \\
\hline $\operatorname{LOSS}_{t-1}$ & $0.67 * *$ & 0.04 & $0.67 * *$ & 0.04 \\
\hline$S T D_{-} C F O_{t}$ & $1.64 * *$ & 0.03 & $1.59 * *$ & 0.04 \\
\hline$H E R F_{t-1}$ & -1.77 & 0.72 & -2.11 & 0.67 \\
\hline LISTED $_{t}$ & 0.06 & 0.88 & 0.06 & 0.15 \\
\hline OWNERSHIP & -1.21 & 0.14 & -1.23 & 0.13 \\
\hline$L B O A R D \_S I Z E_{t-1}$ & -0.51 & 0.10 & -0.48 & 0.13 \\
\hline Industry fixed effects & Yes & & Yes & \\
\hline $\mathrm{N}$ & 13,505 & & 13,505 & \\
\hline Area under the ROC curve & 0.81 & & 0.81 & \\
\hline
\end{tabular}

This table presents the results from estimating logistic regression of the likelihood of an accounting misstatement in the current year as a function of an announced accounting restatement (made by another client of the same engagement partner) in the two and three preceding years. The sample consists of client-year observations from 1996 through 2010. Two-tailed $p$-values are based on cluster-robust standard errors (clustered by audit client and year). *, **, *** denote significance of $0.1,0.05$, and 0.01 level, respectively. See the Appendix for variable definitions. 
Table 6

The Effect of Engagement Partner Reputation on Client Turnover and on Client Gains

Panel A: Descriptive Statistics $(\mathrm{N}=12,174)$

\begin{tabular}{|c|c|c|c|c|c|c|c|}
\hline Variable & MEAN & STD & Q1 & MED & Q3 & MIN & MAX \\
\hline CH_PARTNER ${ }_{t}$ & 0.13 & 0.34 & 0.00 & 0.00 & 0.00 & 0.00 & 1.00 \\
\hline PREDECESSOR_RESTATE2 & 0.18 & 0.38 & 0.00 & 0.00 & 0.00 & 0.00 & 1.00 \\
\hline SUCCESSOR_RESTATE2 & 0.17 & 0.38 & 0.00 & 0.00 & 0.00 & 0.00 & 1.00 \\
\hline PREDECESSOR_RESTATE3 & 0.23 & 0.42 & 0.00 & 0.00 & 0.00 & 0.00 & 1.00 \\
\hline SUCCESSOR_RESTATE3 & 0.23 & 0.42 & 0.00 & 0.00 & 0.00 & 0.00 & 1.00 \\
\hline$L_{A S S E T}$ & 14.81 & 1.31 & 13.85 & 14.65 & 15.58 & 12.32 & 18.66 \\
\hline$\triangle A S S E T_{t}$ & 0.16 & 0.31 & -0.02 & 0.08 & 0.24 & -0.36 & 1.60 \\
\hline$A B S \_D A C C_{t}$ & 0.09 & 0.09 & 0.03 & 0.06 & 0.11 & 0.00 & 0.46 \\
\hline$M A O_{t}$ & 0.50 & 0.50 & 0.00 & 1.00 & 1.00 & 0.00 & 1.00 \\
\hline$R O A_{t}$ & 0.05 & 0.11 & 0.01 & 0.05 & 0.10 & -0.37 & 0.31 \\
\hline$G C_{t}$ & 0.02 & 0.15 & 0.00 & 0.00 & 0.00 & 0.00 & 1.00 \\
\hline$L O N G \_P A R T N E R \_T E N U R E_{t-1}$ & 0.46 & 0.50 & 0.00 & 0.00 & 1.00 & 0.00 & 1.00 \\
\hline $\operatorname{LOSS}_{t}$ & 0.21 & 0.41 & 0.00 & 0.00 & 0.00 & 0.00 & 1.00 \\
\hline LISTED $_{t}$ & 0.68 & 0.47 & 0.00 & 1.00 & 1.00 & 0.00 & 1.00 \\
\hline$L E V_{t}$ & 0.40 & 0.18 & 0.27 & 0.40 & 0.52 & 0.07 & 0.93 \\
\hline$\Delta L E V_{t}$ & 0.06 & 0.18 & -0.04 & 0.02 & 0.11 & -0.30 & 0.83 \\
\hline$I N V R E C_{t}$ & 0.32 & 0.19 & 0.18 & 0.29 & 0.43 & 0.01 & 0.84 \\
\hline$C A S H_{t}$ & 0.10 & 0.11 & 0.02 & 0.06 & 0.12 & 0.00 & 0.53 \\
\hline$A R \_I N_{t}$ & 0.32 & 0.19 & 0.18 & 0.29 & 0.43 & 0.00 & 0.97 \\
\hline FOREIGN & 0.44 & 0.36 & 0.05 & 0.43 & 0.79 & 0.00 & 1.01 \\
\hline FINANCING $_{t}$ & 0.38 & 0.49 & 0.00 & 0.00 & 1.00 & 0.00 & 1.00 \\
\hline OWNERSHIP $_{t}$ & 0.30 & 0.17 & 0.17 & 0.27 & 0.39 & 0.00 & 1.00 \\
\hline$F I R M \_T E N U R E_{t}$ & 8.96 & 5.07 & 5.00 & 8.00 & 12.00 & 2.00 & 24.00 \\
\hline$L B O A R D \_S I Z E_{t}$ & 2.00 & 0.29 & 1.79 & 2.08 & 2.08 & 1.39 & 3.00 \\
\hline$S T D \_C F O_{t}$ & 0.12 & 0.14 & 0.05 & 0.08 & 0.14 & 0.01 & 0.90 \\
\hline$H E R F_{t}$ & 0.06 & 0.08 & 0.02 & 0.03 & 0.06 & 0.01 & 0.38 \\
\hline$B i g \_N_{t}$ & 0.85 & 0.36 & 1.00 & 1.00 & 1.00 & 0.00 & 1.00 \\
\hline
\end{tabular}

This panel summarizes the descriptive statistics for the audit partner turnover sample used to estimate Equation (5). See the Appendix for variable definitions. 
Panel B: The Effects of Partner Reputation on the Likelihood of Partner Turnover

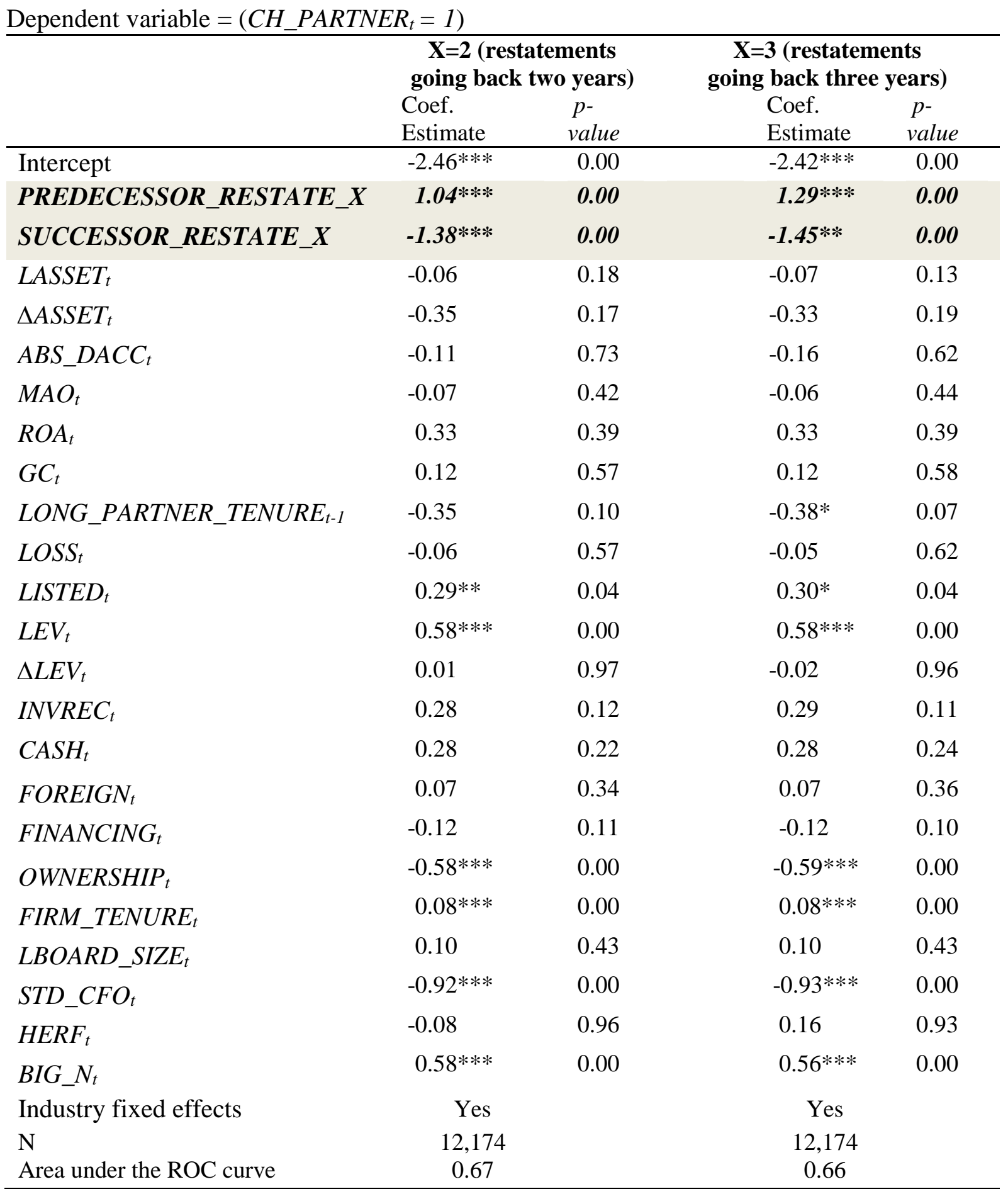

This panel presents the results from regressing changes in engagement partners in year $t$ on predecessor and successor engagement partner reputation variables. Two-tailed $p$-values are based on cluster-robust standard errors (clustered by audit client and year). *,**,*** denote significance of $0.1,0.05$, and 0.01 level, respectively. See the Appendix for variable definitions. 